\title{
Glulam beams: Performance of PVA and PUR Adhesives on Bending Strengths of Locally Selected Nigerian Timber Species
}

\author{
C. Arum $^{\mathrm{a}}$, I. O. Olofintuyi ${ }^{\mathrm{b}, *}$, O. O. Ekundayo ${ }^{\mathrm{c}}$ \\ ${ }^{a}$ Department of Civil Engineering, Federal University of Technology Akure, Ondo State, NIGERIA. \\ ${ }^{b}$ Department of Civil Engineering, Federal Polytechnic, Ado-Ekiti, Ekiti State, NIGERIA. \\ ${ }^{c}$ Department of Building Technology, Federal University of Technology Akure, Ondo State, NIGERIA.
}

\begin{abstract}
The applicability of structural timber to construction is due to its desirable qualities such as lightweight, aesthetics and eco-friendliness. However, continuous use of timber for structural purposes comes with the challenge posed by the anisotropic nature of various timber species. Advanced societies have developed and modified their sawn timber species in form of glue-laminated structural members such as beams, columns, joist etc. Nigeria timber species are yet to be fully explored along glued-laminated beams production. This paper assesses the suitability of three selected Nigerian timber species namely; Gmelina Arborea (ML), Terminalia superba (AF) and Pycnanthus angolensis (AK) for production of glued-laminated (glulam) beams. They are locally known respectively as Melina $(M L)$, Afara (AF) and Akomu (AK). The applicability and glue-ability of the glues and their ultimate effect on the flexural strength were investigated through the use of two different types of glue components namely; polyvinyl acetate (PVA) and polyurethane (PUR) glue. The physical properties of the timber species such as moisture content $(M C)$ and densities were determined using BS EN 408. The beams produced which are $1680 \mathrm{~mm}$ by $150 \mathrm{~mm}$ by $120 \mathrm{~mm}$ in dimension were subjected to two points loading system to determine their flexural strengths and failure loads in accordance with ASTM D-198. The flexural strengths results indicated that Pycnanthus angolensis offered most resistance to bending loads with an average flexural strength value of $16.04 \mathrm{~N} / \mathrm{mm}^{2}$ when PUR glue was used and $13.04 \mathrm{~N} / \mathrm{mm}^{2}$ when PVA glue was used. The ANOVA result showed that glue types have significant effect on the flexural strength at confidence level of 95\%. It was concluded that Pycnanthus angolensis is most suitable for structural applications. PUR is considered the better glue in terms of strength and glue-ability while PVA glue is considered better in terms of workability and applicability based on almost perfect glue line integrity achieved.
\end{abstract}

Keywords: glued-laminated, flexural strength, modulus of elasticity, timber, polyurethane, polyvinyl acetate

\section{INTRODUCTION}

The approach to the use of timber in the Nigerian construction industry has been largely traditional. The construction industry has not taken advantage of the remarkable merits of valueadded wood products like glued laminated timber. In many advanced societies, the emergence of this technology has positively impacted not just the construction industry but also allied sectors that span across both forest and adhesives industries. While Nigeria has vast timber resources populated with diverse species, there are no sufficient antecedents in literature and in practice to show that sufficient data has been established as necessary in developing value-added engineered

\footnotetext{
* Corresponding author (Tel: +234 (0)806 479 8010)

Email addresses: arumcnwchrist@yahoo.co.uk (C. Arum), olofintuyi_io@fedpolyado.edu.ng (I. O. Olofintuyi), ooekundayo@futa.edu.ng (O. O. Ekundayo)
}

wood products such as glulam using local timber species. Experimental inquisition into the suitability of locally grown timber species for structural glulam holds the key to identifying species that satisfy both gluing and mechanical requirements for glulam. Hence, deliberate tree cultivation efforts can be undertaken to sustain the raw material supply of such species to feed the innovative technology. More importantly, this could facilitate the critical nexus needed to make both the construction industry and the forestry sector mutually and sustainably thrive. Furthermore, jointing is a critical factor to the successful use of structural timber. While mechanical jointing has been in use in structural wood, the high embodied energy coupled with the high fiber failure and yielding of mechanical joints at the wood-metal interface makes this method of jointing undesirable. On the contrary, wood gluing has shown remarkable performance in achieving structurally 
viable bonds at joined interface with a low carbon foot print. This particularly makes glue lamination attractive. Potentially, investigating the suitability of a wide array of local species for glulam could open up investment opportunities in the adhesives industry, thereby fostering the industrial clusters needed to sustain profitability within the associated industries. Similarly, this could broaden the innovative latitude for engineers and designers in terms of choice of material and design possibilities. Currently, not much has been reported on the success or failure at structural glue lamination of local timber species. Although some studies have shown the possibility of structurally gluing local timber, howbeit, these studies have only considered the use of polyvinyl acetate glue out of the wide variety of synthetic wood glues available [1, 2]. However, there are several synthetic resins in use for wood lamination. Many of these have not been tested on Nigerian grown wood species. The use and application of many known wood adhesives have been extensively discussed in [3]. In a comparative study of mechanical properties of some Nigeria timber species using solid wood specimens, three timber species namely Gmelina Arborea, Parkia Biglobosa and Prosopis Africana were investigated for bending strength, tensile strength, modulus of elasticity and shear strength [4]. Their investigation showed that Gmelina Arborea, has flexural strength of $12.5 \mathrm{~N} / \mathrm{mm}^{2}$ when subjected to third point flexural loading system.

Literature revealed that Terminalia superba belongs to non-durable type of timber easily attacked by defects; however non-durability is not a serious defect and timbers should not be rejected based on that as opined by [5]. In a mechanical characterization and grading of Irvingia gabonensis timber species in which tests on two points bending, compression parallel and perpendicular, shear parallel and tension parallel to grain were carried out [6], it was concluded that Irvingia gabonensis is a hardwood (D Class) of D70 strength class and N1 strength group according to $[7,8]$ with good Engineering properties and can be used as beams, columns, rafters, railway sleepers and timber bridge materials. The physical properties of Abizia zygia and Anogeissus leiocarpus, were determined and classified as medium grade wood species on the basis of their density values [8]. It was also established that Terminalia superba belongs to low grade species according to the characterization carried out by Beak Consultants Limited and cited by [8].

In summary, Nigerian timber species investigated by various researchers are suitable for glued-laminated beams production based on the results obtained for their mechanical properties. However, there is still much to be done in terms of standardization of various species to meet Engineered Wood Products (EWP) specification. Data on the performance of synthetic resins for glue laminating timber in Nigeria is non- existent.

Furthermore, this research recognizes the importance of widening the range of timber species available for lamination to reduce the pressure on only a few species. Consequently, this study is concerned with testing and comparing the performance of Polyurethane and Polyvinyl acetate adhesives on locally grown wood species for glulam production on bending strength.

\section{MATERIALS AND METHODS}

\subsection{Materials}

The materials used for this research include three visually graded timber species locally sourced from Ado- Ekiti, Ekiti State of Nigeria. These species are Gmelina Arborea, Terminalia superba and Pycnanthus angolensis; polyvinyl acetate and polyurethane glues conforming to [2] respectively were used. Wood processing machines such as electronically operated circular saw machine, planing and thicknessing machine which are available at Wood workshop of Building Technology Department, Federal Polytechnic, Ado-Ekiti were used to convert the species to desired dimensions. The glues were uniformly and gently applied on already prepared surface prior to cramping. The glue line integrity was ensured to be in accordance with [9] by applying sufficient pressure on the laminates. The Flexural testing machine which is of $100 \mathrm{kN}$ capacity is of dual loading system i.e., center point and two points loading systems. The deflection was measured through a deflectometer attached to the machine (Fig. 3).

\subsection{Methods}

Preliminary tests to determine the physical properties (moisture content and density) of wood were carried out using three (3) numbers of specimen dimensions $50 \mathrm{~mm} \times 50 \mathrm{~mm} \times 50 \mathrm{~mm}$ per species in line with [9]. In order to allow natural drying process to take place, the species were subjected to natural seasoning until the moisture content dropped to acceptable level of $10 \%-18 \%$ according to [9] prior to commencement of GLULAM production. The wood was thereafter cut to dimensions $1680 \mathrm{~mm} \times 150 \mathrm{~mm} \times 20 \mathrm{~mm}$ the spandepth ratio of $\leq 12$ was achieved as specified in [1] and the laminates of $20 \mathrm{~mm}$ were later glued together in six layers to form $120 \mathrm{~mm}$ depth (Fig. 1). A total number of 15 specimens were prepared for polyurethane glue and 15 specimens for polyvinyl acetate glue (Fig. 2) to make the 6-member layup (Fig. 1). This represents 5 specimens of beams per species for each glue type totaling 30 numbers. Each of the 6-member lay-up was then subjected to static bending test (figure 3). Moisture contents and densities of the glued laminated beams were determined by cutting a $120 \mathrm{~mm}$ by $100 \mathrm{~mm}$ by $50 \mathrm{~mm}$ size close to region of failure (Fig. 5) from the failed beams. Flexural strength for two point loading was calculated using Eq. (1) [10].

$$
\text { Flexural strength }\left(f_{m}\right)=\frac{a \mathrm{P}_{\max }}{2 \mathrm{Z}}
$$

where;

" $\mathrm{P}_{\text {max }}$ " is maximum applied load $(\mathrm{N})$ 


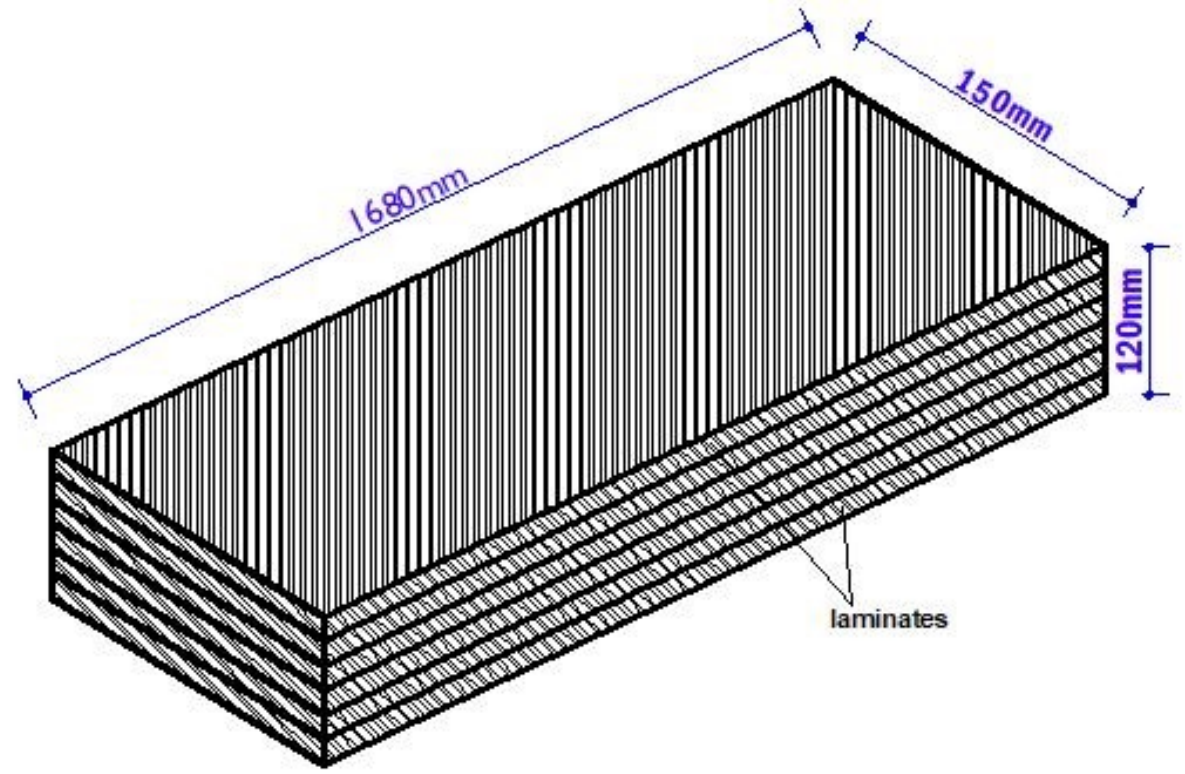

Figure 1: Illustration of member lay-up.

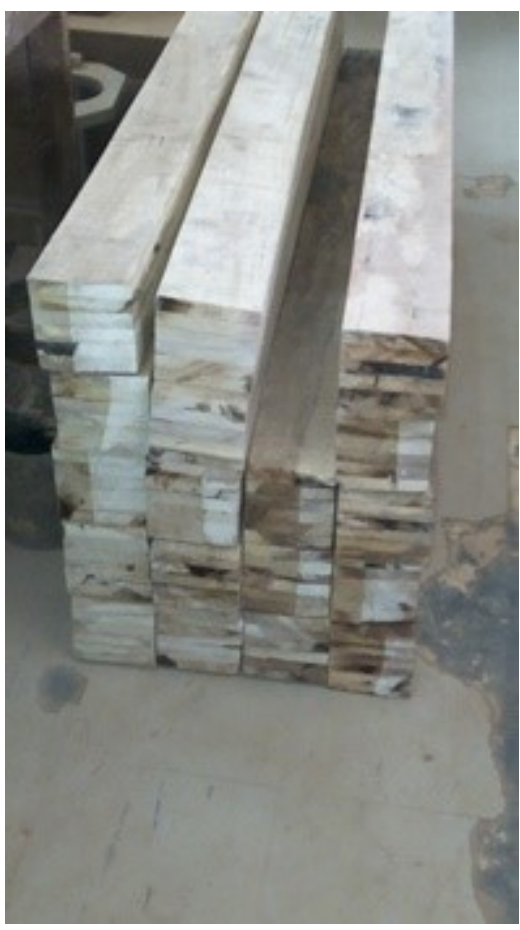

Figure 2: Section of produced glued-laminated beam.

" $a$ " is the distance from point of load application to bearing/support ( $\mathrm{mm})$; and

$\mathrm{Z}$ is the section modulus $=\frac{b d^{2}}{6}$

where

" $b$ " is width of the material specimen $(\mathrm{mm})$ " $d$ " is average depth of the specimen ( $\mathrm{mm}$ )

In order to make adjustment to the bending strength obtained from the bending test, the results obtained from Eq. (1) above were multiplied

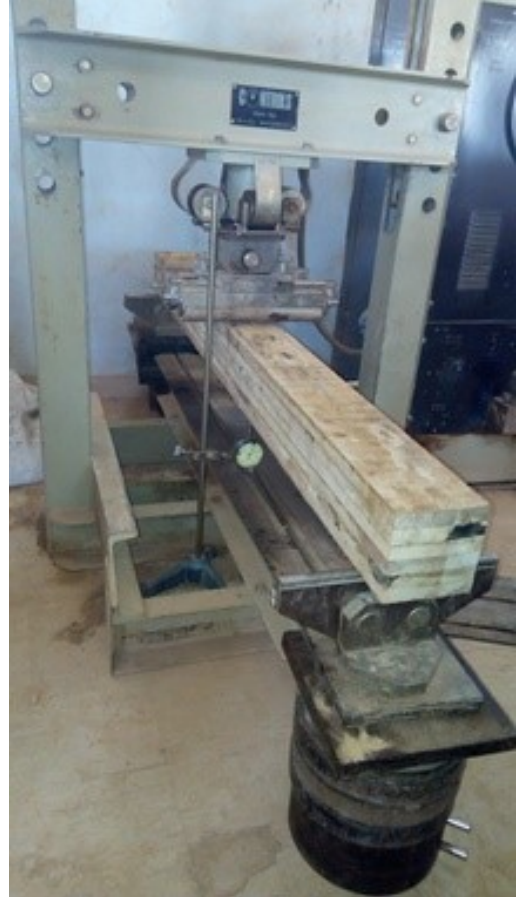

Figure 3: Two points static bending test setup.

by volume correction factor as given by Eq. (3). This volume correction factor is as specified by [11]

$$
\mathrm{C}_{\mathrm{V}}=\left(\frac{130}{b}\right)^{\alpha}\left(\frac{105}{h}\right)^{\alpha}\left(\frac{6400}{1}\right)^{\alpha}
$$

where $\alpha=1 / 10$ for the three species, Gmelina Arborea, Pycnanthus angolensis and Terminalia superba and; $b, h$ and $l$ are the beam width, beam depth and beam span in $\mathrm{mm}$, respectively.

In order to adjust the characteristic values of bending strength from the measured MC to $18 \%$, 


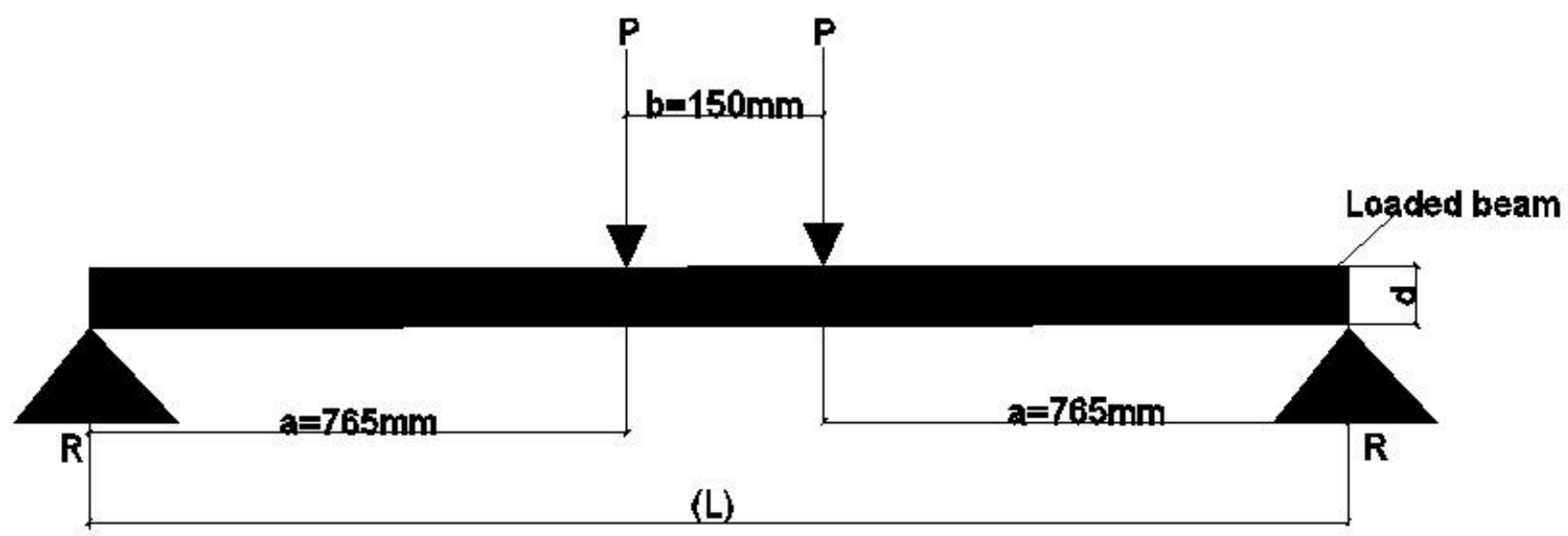

Figure 4: Illustration of two points symmetrical loading system.

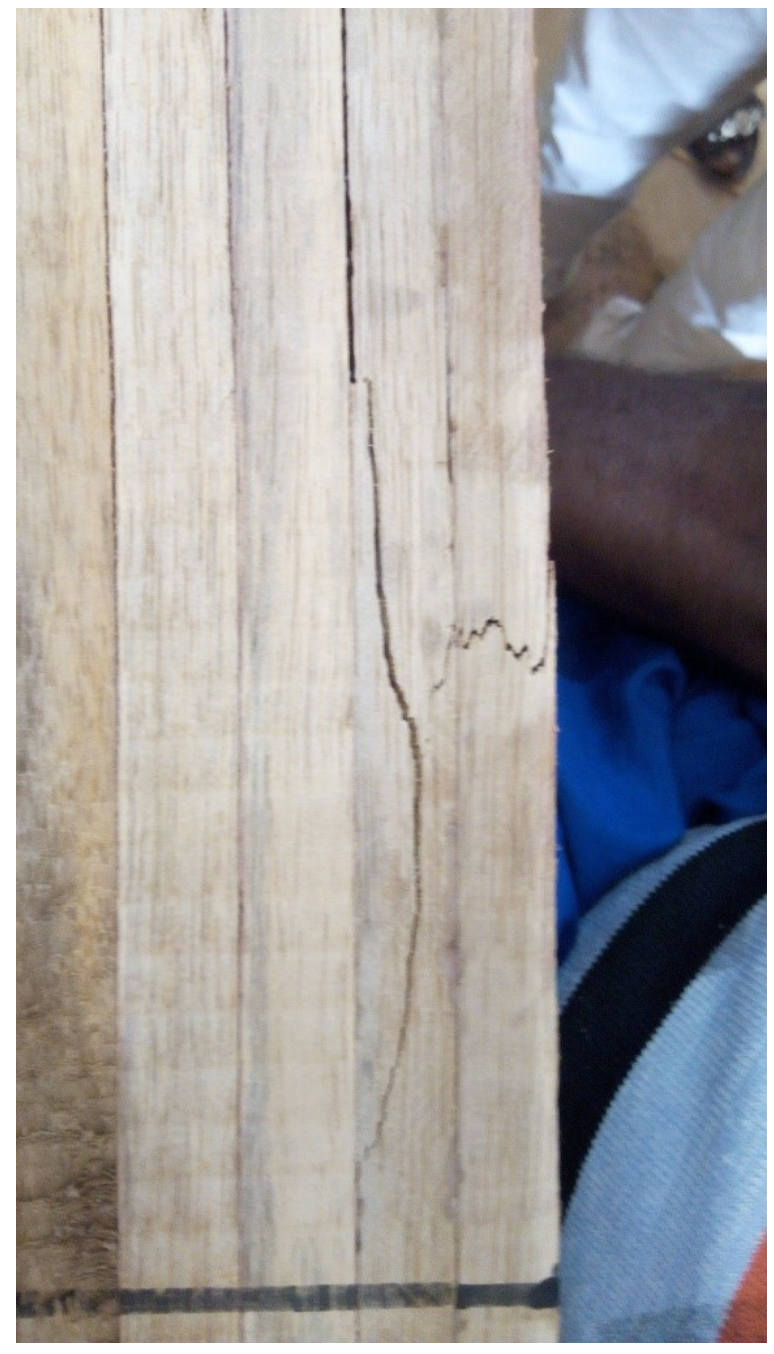

Figure 5: Section through the beam showing failure. bending strength values in line with local environmental condition [12] was computed using Eq. (4):

$$
f_{m k, 18 \%}=\frac{f_{\text {measured }}}{1+0.0295(18-U)}
$$

where $f_{m k, 18 \%}$ is the characteristic bending strength at $18 \%$ moisture content; $U$ is the measured moisture content in (\%) and $f_{\text {measured }}$ is the characteristic bending strength $\left(\mathrm{N} / \mathrm{mm}^{2}\right)$ at the test moisture content. The adjusted density to MC of $18 \%$ was computed using Eq. (5) [12].

$$
\rho_{k, 18 \%}=\rho_{w}\left[\frac{1-(1-0.5)(U-18)}{100}\right]
$$

$\rho_{w}$ is the characteristic density at the time of testing and $U$ is the moisture content at the time of test.

The two-point bending strength tests as specified by [10] is used to carry out tests on the mechanical properties of glued laminated beams. Figure 4 illustrates the typical setup for a twopoint loading system used in this research.

\section{RESULTS AND DISCUSSION}

\subsection{Mean Moisture Contents and Density of} wood species

Table 1 shows the Moisture content (MC) results in which after seasoning, the moisture contents dropped drastically for all the species with $\mathrm{ML}, \mathrm{AF}$ and $\mathrm{AK}$ having values of $14.20 \%, 14.63 \%$ and $14.43 \%$ respectively for PVA glue and $14.72 \%$, $13.72 \%$ and $14.74 \%$ respectively for PUR glue. The table shows that, the standard deviations of $\mathrm{AF}$ is the highest of all the 3 species with values of $1.4 \%$ and $1.06 \%$ for PVA and PUR glues respectively. The MCs all conform to [9] and all fall within the recommended range of $11 \%-18 \%$ for glued laminated beams production. 
Table 1: Physical properties of wood species.

\begin{tabular}{|c|c|c|c|c|c|c|c|c|c|}
\hline Botanical name & $\begin{array}{l}\text { Glue } \\
\text { Type }\end{array}$ & $\begin{array}{c}\text { Mean } \\
\text { MC } \\
(\%)\end{array}$ & $\begin{array}{l}\mathbf{S D}_{\mathbf{M C}} \\
\left(\sigma_{\mathbf{M C}}\right)\end{array}$ & $\begin{array}{l}\text { COV } \\
\text { (MC) }\end{array}$ & $\begin{array}{c}\text { Mean } \\
\text { Density } \\
\left(\mathbf{k g} / \mathbf{m}^{3}\right)\end{array}$ & $\begin{array}{c}\text { Character- } \\
\text { istic Density } \\
\left(\mathbf{k g} / \mathbf{m}^{3}\right.\end{array}$ & $\begin{array}{c}\text { Adjust } \\
\text { Density } \\
\left(\mathbf{k g} / \mathbf{m}^{3}\right)\end{array}$ & $\begin{array}{l}\mathbf{S D}_{(a d j \rho)} \\
\left(\sigma_{(a d j \rho)}\right)\end{array}$ & $\mathbf{C O V}_{(a d j \rho)}$ \\
\hline (Gmelina arborea $)$ - ML & PVA & 14.20 & 0.36 & 0.02 & 402.60 & 388.52 & 406.93 & 8.53 & 0.02 \\
\hline (Terminalia superba) - AF & PVA & 14.63 & 1.40 & 0.96 & 363.80 & 355.12 & 375.62 & 5.26 & 0.02 \\
\hline $\begin{array}{l}\text { (Pycnanthus } \\
\text { angolensis) - AK }\end{array}$ & PVA & 14.43 & 0.86 & 0.05 & 326.40 & 301.42 & 336.67 & 15.14 & 0.05 \\
\hline $\begin{array}{l}\text { angolensts)-AK } \\
\text { (Gmelina arborea)- ML }\end{array}$ & PUR & 14.72 & 0.58 & 0.04 & 424.80 & 362.30 & 432.09 & 37.88 & 0.09 \\
\hline (Terminalia superba)-AF & PUR & 13.72 & 1.06 & 0.08 & 326.40 & 303.14 & 332.70 & 14.10 & 0.04 \\
\hline $\begin{array}{l}\text { (Pycnanthus } \\
\text { angolensis)-AK }\end{array}$ & PUR & 14.74 & 0.79 & 0.05 & 336.13 & 318.91 & 342.67 & 10.44 & 0.03 \\
\hline
\end{tabular}

Table 2: Mean moisture content results of glued-laminated beams.

\begin{tabular}{lcccc}
\hline $\begin{array}{l}\text { Timber Species } \\
\text { (Botanical name) }\end{array}$ & \multicolumn{2}{c}{ Glue Type } & Mean MC (\%) & Standard Deviation $(\sigma)$ Coefficient of variation \\
(Gmelina arborea) ML & PVA & 13.85 & 0.95 & 0.06 \\
(Terminalia superba) AF & PVA & 11.50 & 0.58 & 0.05 \\
(Pycnanthus angolensis) AK & PVA & 11.71 & 0.43 & 0.04 \\
(Gmelina arborea) ML & PUR & 12.57 & 0.51 & 0.04 \\
(Terminalia superba) AF & PUR & 14.14 & 1.37 & 0.10 \\
(Pycnanthus angolensis) AK & PUR & 14.11 & 0.34 & 0.02 \\
\hline
\end{tabular}

\subsection{Mean Moisture Contents of Glued Lami- nated Beams}

Table 2 shows the results of MC of the glued laminated beams after flexural test has been carried out. Out of the three species the highest MC was recorded for ML when using PVA glue but with PUR glue its (ML) moisture content is the least at $12.57 \%$. It also shows the most dispersion with $0.95 \%$ standard deviation and coefficient of variation of 0.06 for PVA glue. On the other hand, AF deviated most for PUR glue having a value of $1.37 \%$ and coefficient of variation of 0.097 .

\subsection{Bending Strength}

Figure 5 is a section of one of the failed beams in tension and Table 3 presents the results of bending strength test. The figure indicates that the glued-laminated beam failed through the laminates and not through the glue line which is an indication of perfect glue-line integrity. Table 3 shows the bending strength of the various species tested. Equation (3) was used to correct the bending strength. Figure 6 shows the relationship between the load and the bending strengths, significant increase in strength was witnessed between PVA and PUR glue with PUR glue having higher flexural strength for all species. Figure 7 is a graphical illustration of the mean flexural strength obtained against the glues. The graph shows that PUR produced higher bending strength than PVA glue; this can be attributed to its strong bonding. Furthermore, Figure 8 is the graphical illustration of the mean flexural strengths obtained against the species. The evaluation of flexural strengths in terms of species is necessary to give the construction industry and timber users a general knowledge of the usefulness of each of the selected species according to the flexural strengths. The species have their individual uniqueness and properties coupled with distinctly dissimilar nature of timber. The bending strength evaluated provided one of the most important parameters used to adequately describe timber species. ML species generally is considered a relatively hard wood, hence its surface would not allow easy penetration of glue because of compacted grains, while AK is generally considered as soft species, hence the ease of penetration of glue to form perfect laminated beams and hence produce higher bending strength. The corrected bending strengths showed that $\mathrm{AK}$ has the highest bending strength of $13.04 \mathrm{~N} / \mathrm{mm}^{2}$ and $16.04 \mathrm{~N} / \mathrm{mm}^{2}$ respectively for PVA and PUR glues. The least was ML having $9.01 \mathrm{~N} / \mathrm{mm}^{2}$ and $12.66 \mathrm{~N} / \mathrm{mm}^{2}$ respectively for PVA and PUR glues. The high flexural strength may be attributed to the ease of penetration of glue in deciduous (AK) wood.

\subsection{Weight of Glued Laminated Beams}

Table 4 shows the weight of the laminated beams prior to testing for flexure. The result shows that ML has mass range of $15.90 \mathrm{~kg}-$ $19.50 \mathrm{~kg}$ range when compared with other wood species when PVA glue is used while AK has mass range of $11.5 \mathrm{~kg}-12.40 \mathrm{~kg}$ when PVA glue is used. The highest mass recorded in ML is due primarily to the density of the wood grains

where $\alpha=0.05$

\subsection{Statistical Analysis (ANOVA)}

The ANOVA result shows that $\mathrm{P}$-value is very low at 0.024461 and Fcal. is greater than Fcrit., $\mathrm{P}$-value is less than $\alpha$, implying that there is significant effect of glue types on the flexural strength obtained from each species at confidence level of 95\%. Pycnanthus angolensis produced 
Table 3: Mean bending strength of glulam beams.

\begin{tabular}{|c|c|c|c|c|c|c|c|}
\hline $\begin{array}{l}\text { Timber Species } \\
\text { (Botanical Name) }\end{array}$ & $\begin{array}{l}\text { Glue } \\
\text { Type }\end{array}$ & $\begin{array}{c}\text { Max } \\
\text { Load } \\
(\mathbf{N})\end{array}$ & $\begin{array}{l}\text { Measured } \\
\text { Bending } \\
\text { strength } \\
\left(\mathbf{N} / \mathbf{m m}_{2}\right)\end{array}$ & $\begin{array}{c}\text { Characteristics } \\
\text { Bending } \\
\text { strength } \\
\left(\mathbf{N} / \mathbf{m m}_{2}\right)\end{array}$ & $\begin{array}{c}\text { Corrected } \\
\text { Bending } \\
\text { strength } \\
\left(\mathrm{N} / \mathrm{mm}_{2}\right)\end{array}$ & $\begin{array}{l}\text { Standard } \\
\text { Deviation } \\
\quad(\sigma)\end{array}$ & $\begin{array}{c}\text { Coefficient } \\
\text { of variation } \\
\text { (COV) }\end{array}$ \\
\hline (Gmelina Arborea)ML & PVA & 9180.00 & 7.27 & 7.33 & 9.01 & 4.12 & 0.20 \\
\hline (Terminalia superba)AF & PVA & 12800.00 & 10.13 & 10.23 & 12.57 & & \\
\hline (Pycnanthus angolensis)AK & PVA & 13280.00 & 10.51 & 10.70 & 13.04 & 3.11 & 0.10 \\
\hline (Gmelina Arborea) ML & PUR & 12900.00 & 10.21 & 10.31 & 12.66 & 5.08 & 0.17 \\
\hline (Terminalia superba) AF & PUR & 15260.00 & 12.94 & 13.05 & 14.98 & 13.75 & 0.40 \\
\hline (Pycnanthus angolensis)AK & PUR & 16340.00 & 12.08 & 12.20 & 16.04 & 14.95 & 0.40 \\
\hline
\end{tabular}

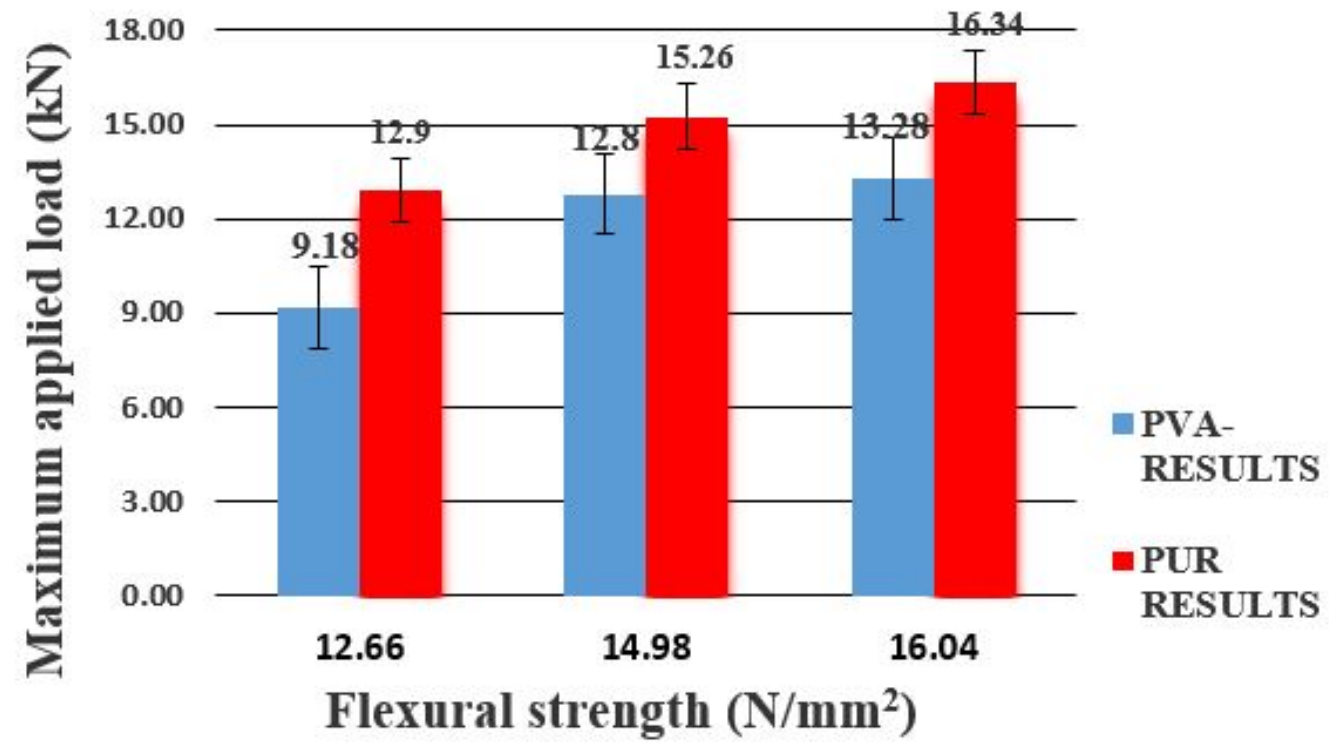

Figure 6: Bar chart showing relationship between the Loads and Flexural strength for each type of glue.

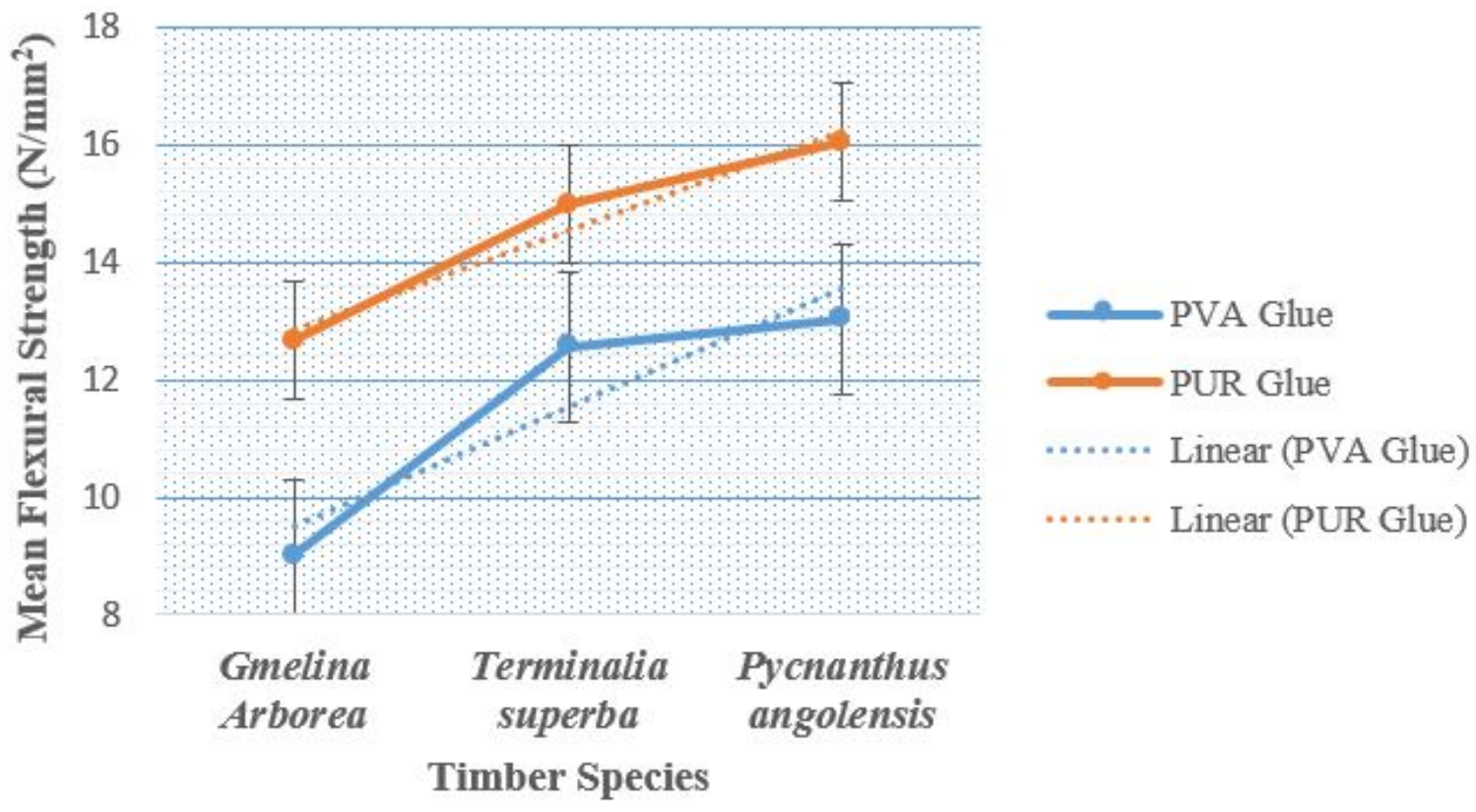

Figure 7: Graph of mean (Corrected) flexural strength against timber species. 


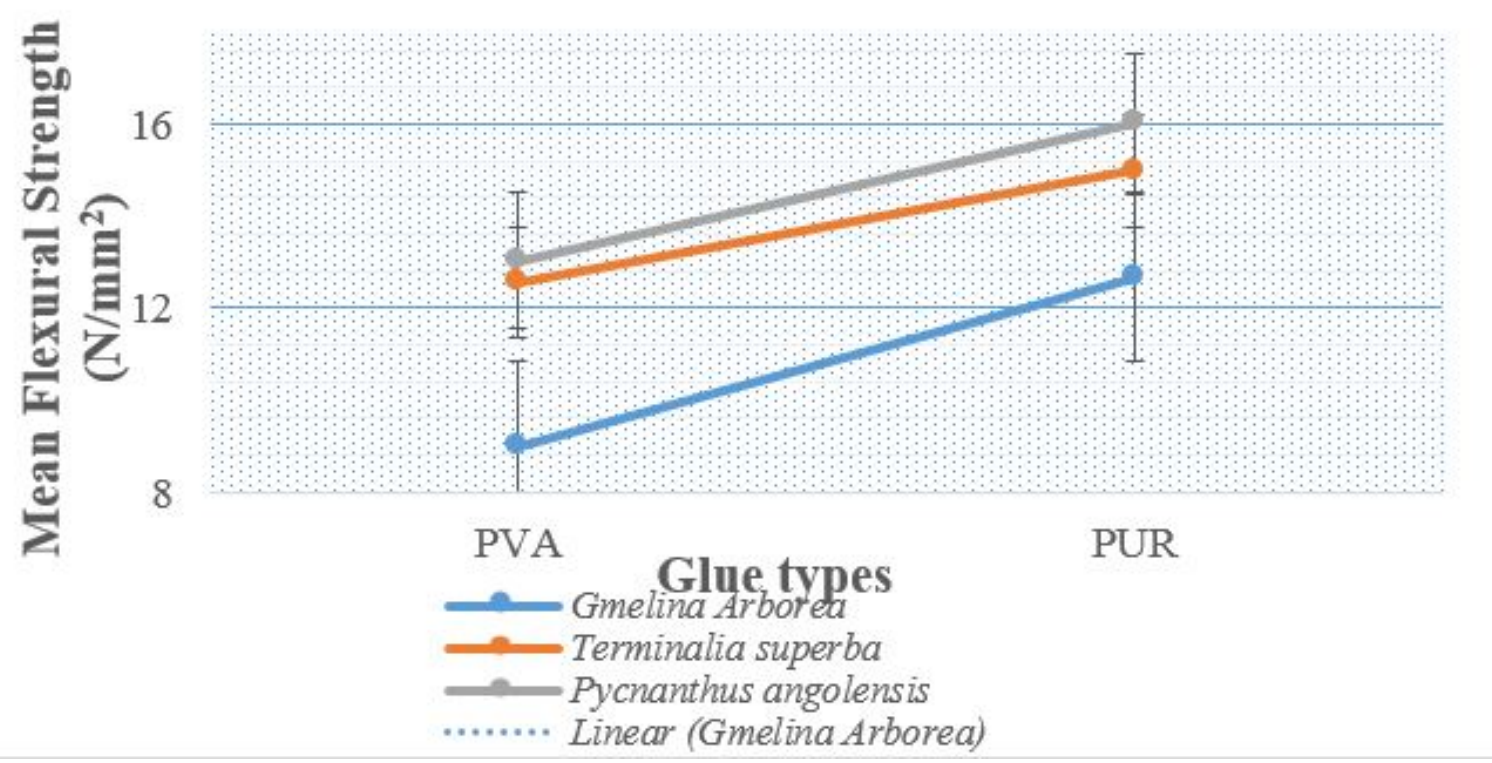

Figure 8: Graph of mean flexural strength against the glue types.

Table 4: Mass of beams before flexural tests.

\begin{tabular}{|c|c|c|c|c|c|c|}
\hline $\mathbf{S} / \mathbf{N}$ & PVA-(ML) (kg) & PUR-(ML)(kg) & PVA-(AF) (kg) & PUR-(AF) (kg) & PVA-(AK) (kg) & PUR-(AK) (kg) \\
\hline 1 & 15.90 & 11.70 & 11.50 & 10.1 & 12.10 & 9.2 \\
\hline 2 & 19.50 & 11.9 & 10.90 & 10.8 & 12.30 & 9.3 \\
\hline 3 & 18.00 & 12.40 & 10.90 & 9.50 & 12.40 & 8.8 \\
\hline 4 & 17.20 & 13.00 & 10.60 & 9.60 & 11.50 & 9.00 \\
\hline 5 & 16.20 & 13.20 & 11.70 & 9.80 & 11.60 & 8.60 \\
\hline
\end{tabular}

Table 5: Analysis of variance (Two way without repetition).

\begin{tabular}{llllllc}
\hline ANOVA & & & & & & \\
Source of Variation & SS & $\boldsymbol{d}$ & $\boldsymbol{M S}$ & $\boldsymbol{F}$ & $\mathbf{P}_{\text {value }}$ & $\mathbf{F}_{\text {crit }}$ \\
\hline Rows & 81.037 & 2 & 40.522 & 39.882 & 0.0245 & 19 \\
Columns & 72.794 & 1 & 72.794 & 71.65 & 0.0134 & 18.51 \\
Error & 2.032 & 2 & 1.016 & & & \\
Total & 155.8645 & & & & & \\
\hline
\end{tabular}

Table 6: Analysis of Variance (Two way without repetition).

\begin{tabular}{lllll}
\hline Summary & Count & Sum & Average & Variance \\
\hline Gmelina Arborea, ML & 2 & 49.94036 & 24.97018 & 35.39656 \\
Terminalia superba, AF & 2 & 66.99427 & 33.49713 & 23.95069 \\
Pycnanthus angolensis, AK & 2 & 63.46587 & 31.73294 & 15.47909 \\
PVA & 3 & 79.75077 & 26.58359 & 25.70197 \\
PUR & 3 & 100.6497 & 33.54991 & 15.83276 \\
\hline
\end{tabular}

Table 7: Analysis of Variance (Two way without repetition).

\begin{tabular}{lcccc}
\hline S/N & Species-Glue & Flexural Strength $\left(\mathbf{N} / \mathbf{m m}^{2}\right)$ & ANSI Recommended Range $\left(\mathbf{N} / \mathbf{m m}^{2}\right)$ & Stress Class \\
\hline 1 & ML-PVA & 9.01 & $6.38-11.03$ & $16 \mathrm{~F}-\mathrm{V} 6$ \\
2 & AF-PVA & 12.57 & $7.58-13.78$ & $20 \mathrm{~F}-\mathrm{V} 6$ \\
3 & AK-PVA & 13.04 & $7.58-13.78$ & $20 \mathrm{~F}-\mathrm{V} 6$ \\
4 & ML-PUR & 12.66 & $7.58-13.78$ & $20 \mathrm{~F}-\mathrm{V} 6$ \\
5 & AF-PUR & 14.98 & $10.00-16.55$ & $24 \mathrm{~F}-\mathrm{V} 6$ \\
6 & AK-PUR & 16.04 & $\mathrm{v} 10.00-16.55$ & $24 \mathrm{~F}-\mathrm{V} 6$ \\
\hline
\end{tabular}


the highest flexural strength when PUR glue is used. Tables 5 and 6 present a brief summary of the Analysis of Variance carried out on the flexural strengths using Microsoft Excel software with Species and Glues as independent variables. There are a total number of three species of timber and a total number of two glue types each contributing to flexural strengths obtained individually and collectively.

where $\alpha=0.05$

\section{CONCLUSION}

The research has shown that, PUR and PVA adhesives play major roles in achieving the desired flexural strengths in glued laminated beams. PUR is much more effective due to its binding power and ensures proper bonding of the laminates. Species also have significant effect on the flexural strengths to be attained as revealed by the ANOVA results. Furthermore, Pycnanthus angolensis indicated the highest flexural strengths while Gmelina Arborea yielded the lowest value. This is due primarily to the fact that glue penetration to grains of softwood is easier. Also, in order to achieve desired flexural strength using Nigeria timber species for glued laminated beams production, Pycnanthus angolensis and PUR will produce the best result. In terms of classification of stress (Table 7), according to [11], ML-PUR of $12.66 \mathrm{~N} / \mathrm{mm}^{2}$ fell within the stress class of 20F-V6 while AF-PUR and AK-PUR fell within the stress class of 24F-V6. Also, both AFPVA and AK-PVA fell within the stress class of 20F-V6 and ML-PVA fell within the stress class of $16 \mathrm{~F}-\mathrm{V} 6$. Based on the above strength classification, the species can be used for structural members such as columns, beams, long-span trusses etc.

From the foregoing, Pycnanthus angolensis is recommended for structural engineers, builders and timber users for structural construction such as column, beams, joists, framings etc. due primarily to its load carrying capacity and bending resistance as revealed in this research. Furthermore, PUR glue has demonstrated its suitability as a structural glue for glulam production better than PVA glue and its hereby recommended for use in structural glulam production.

\section{References}

[1] T. Emetomo, "Flexural strength of solid and glue- laminated timber beams," American Journal of Engineering Science and Technology Research, vol. 3, no. 1, pp. 1-14, September 2015.

[2] B. E. 15425, "Adhesives - one component polyurethane for load bearing timber structures - classification and performance requirements," British Standards Institution, 2008

[3] B. E. 14080, "Timber structures - glued laminated timber and glued solid timber requirements," British Standards Institution, 2013.

[4] C. Ataguba, "A comparative study of some mechanical properties of gmelina arborea, parkia biglobosa and prosopis africana timbers for structural use," International Journal of Technical Research and Applications, vol. 3, no. 3, pp. 320-324, May 2015.
[5] O. Shasanya, "Some Useful Nigerian Timbers, Their Destroying Agents and Measures for Their Prevention," Journal of Natural Sciences Research, vol. 5, no. 15, 2015.

[6] A. Jimoh and R. Rahmon, "Mechanical Characterization and Grading of Irvingia Gabonensis Timber Specie according to British and Nigerian Standards from Kwara State Nigeria. A NNALS of Faculty Engineering Hunedoara," International Journal of Engineering Tome XVI, May 2018.

[7] NCP 2, "The use of timber in construction nigerian standard code of practice, nigerian standard organization," Federal Ministry of Industry, Lagos Nigeria, 1973.

[8] A. Ogunwusi, "Wood properties of Abizia zygia and Anogeissus leiocarpus: medium category wood species found in timber markets in Nigeria. wood species found," Journal of Biology, Agriculture and Healthcare, vol. 2 , no. 11, 2012.

[9] BS EN 408, "Timber structures - structural timber and glued laminated timber," Determination of some physical and mechanical properties, 2003.

[10] B. E. 408, "American standard of testing materials astm d198-02," Standard Test Methods of Static Tests of Lumber in Structural Sizes. USA., 2003.

[11] ANSI/AWC, "National design specification for wood construction," Research Journal of Forestry, vol. 5, pp. 107$114,2015$.

[12] I. Abubakar and A. M. Nabade, "Physical and Mechanical Properties of Some Common Nigerian Timber Species Based on Limit State Design Approach,"Study of Civil Engineering and Architecture, vol. 2, no. 4, pp. 90-93, 2013. 